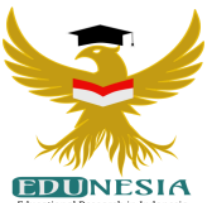

\title{
Manfaat Teknologi Bagi Mata Pelajaran PAI di Masa Pandemi Covid-19
}

\author{
Unik Hanifah Salsabila1; Alvina Agustin²; Feliana Safira ${ }^{3}$; Indrika Sari ${ }^{4}$; \\ Ahmad Sundawa ${ }^{5}$ \\ 1,2,3,4,5Pendidikan Agama Islam, Universitas Ahmad Dahlan, Indonesia \\ ${ }^{1}$ Corresponding Email: unik.salsabila@pai.uad.ac.id, Phone Number : $0822 \times x \times x \times x \times x$
}

\author{
Article History: \\ Received: Nov 09, 2020 \\ Revised: Nov 14, 2020 \\ Accepted: Nov 15, 2020 \\ Published: Jan 01, 2021
}

\section{Keywords:}

Islamic Religious

Education, Education,

Pandemic.

Kata Kunci:

PAI, Pandemi,

Pendidikan.

\section{How to cite:}

Salsabila, U.H., Agustin, A. Safira, F., Sari, I., \& Sundawa A. (2021). Manfaat Teknologi Bagi Mata Pelajaran PAI di Masa Pandemi Covid-19. Edunesia: Jurnal Ilmiah Pendidikan, 2 (1): 125-132.

This is an open access article under the CC-BY-NC-ND license (c) $(9)$
Abstract: Islamic Religious Education is one of the subjects that has a high influence in shaping the personality character of students in schools. Even teachers who teach this lesson usually have an important role in deciding religious matters in school. The occurrence of the Covid-19 pandemic in Indonesia hampered the teaching and learning process in schools. Because of the prohibition, there should not be an excessive number of associations in a place where the face-to-face learning system is replaced by online. In learning with this online system that makes all elements of education responsible for the use of existing technology, in order to create a comfortable learning atmosphere and the material being taught is understood by students. The method we use in this research is the literature study method, in which we examine several journals about technology that can be used for the learning system of Islamic religious education subjects. Even in collecting data, we review it again to adjust to the conditions that existed during the Covid-19 pandemic. The results of our research found that in PAI learning, technology can be very useful and help teachers in teaching Islamic religious education lessons online, because of the Covid-19 pandemic teachers cannot explain the material directly, so by utilizing existing technology the teacher can explain directly online via video conference (Google Meet, Zoom, etc.) besides that, there are also many other features on the internet that teachers can use to provide learning materials online.

Abstrak: Pendidikan Agama Islam (PAI) merupakan salah satu mata pelajaran yang memiliki pengaruh yang tinggi dalam membentuk karakter kepribadian peserta didik di sekolah. Guru yang mengajarkan pelajaran inipun biasanya memiliki peranan penting dalam memutuskan hal-hal yang bersifat keagamaan disekolah. Terjadinya pandemi covid-19 di indonesia menghambat proses belajar mengajar di sekolah. Karna adanya larangan, tidak boleh ada perkumpulan dengan jumlah berlebih disuatu tempat yang membuat sistem pembelajaran tatap muka diganti dengan online. Dalam pembelajaran dengan sistem online inilah yang membuat semua elemen pendidikan untuk bertanggung jawab dalam pemanfaatan teknologi yang ada saat ini, agar dapat menciptakan suasana pembelajaran yang nyaman dan materi yang diajarkanpun dipahami oleh peserta didik. Metode yang kami gunakan dalam penilitian kali ini adalah metode studi literatur, yang dimana kami menelaah beberapa jurnal tentang teknologi yang dapat dimanfaatkan untuk sistem pembelajaran mata pelajaran pendidikan agama islam. Dalam mengumpulkan data pun, kami ulas kembali menyesuaikan dengan kondisi yang ada pada masa pandemi covid-19. Hasil dari penelitian kami mendapatkan bahwasanya dalam pembelajaran PAI, Teknologi dapat sangat bermanfaat dan membantu guru dalam mengajarkan pelajaran pendidikan agama islam secara daring, dikarenakannya pandemi covid-19 ini guru tidak bisa menerangkan materi secara langsung, maka dengan memanfaatkan teknologi yang ada guru dapat menjelaskan secara online via video conference (Google Meet, Zoom, dll) selain itu juga masih banyak lagi fitur-fitur dalam internet yang dapat digunakan guru untuk memberikan materi pembelajaran secara online. 


\section{A. Pendahuluan}

Pendidikan Agama Islam atau biasa dikenal dengan sebutan PAI merupakan salah satu mata pelajaran yang umum terdapat di sekolah negeri dan swasta yang mempunyai posisi penting dalam membentuk, perilaku dan akhlak terpuji para peserta didik. Terdapat dua hal yang menjadi dasar bagi pendidikan agama Islam yaitu Dasar Religius dan Dasar Yuridis. Dasar Religius bersumber dari ajaran Islam yang termaktub dalam Al-Qur'an dan Hadist. Dasar Yuridis Dasar pelaksanaan pendidikan agama berasal dari perundangundangan yang berlaku di Indonesia yang secara langsung atau tidak dapat dijadikan pegangan untuk melaksanakan pendidikan agama.

Muhaimin (2001) mengutip GBPP PAI, Pendidikan Agama Islam adalah usaha sadar untuk menyiapkan siswa dalam memahami, menyakini, menghayati, mengamalkan ajaran islam melalui bimbingan, kegiatan, pengajaran, dan latihan dengan memperhatikan tuntutan untuk menghormati agama lain dalam hubungan kerukunan antar umat beragama di dalam masyarakat untuk mewujudkan persatuan nasional. Singkatnya sebagai upaya yang dilakukan guna meningktkan keimanan, pemahaman dan mengaplikasikan agama Islam melaui pengajaran dan bimbingan agar menjadi pribadi yang baik dan istiqomah dengan kepercayaannya serta bermanfaat bagi agama, orang sekitar, masyarakat dan negara.

Proses pembelajaran yang berlangsung di lingkungan sekolah ialah salah satu kebijakan sebagai upaya untuk meningkatkan ilmu pengetahuan dan keahlian para peserta didik. Beberapa peserta didik beranggapan bahwa sekolah merupakan rumah kedua karena dirasa sangat nyaman dan menyenangkan, mereka dapat beradaptasi dengan mudah serta berkomunikasi, interaksi dengan masyarkat sekolah untuk mengembangkan aspek sosial dan juga emosional. Dapat dikatakan bahwa sekolah merupakan wadah untuk peserta didik berinteraksi agar kemampuan, minat maupun bakat yang dimiliki bisa berkembang bahkan meningkat. Seperti yang kita ketahui, saat ini semua kegiatan pembelajaran di sekolah dihentikan, diganti dengan pembelajaran jarak jauh atau yang biasa disebut daring dari rumah masing-masing karena pandemi Covid-19.

Ada dua dampak bagi pendidikan yang disebabkan pandemi Covid-19. Yang pertama adalah dampak jangka pendek, hal ini dirasakan oleh banyak keluarga di Negara Indonesia khususnya baik di kota maupun desa. Berlangsungnya aktivitas sekolah dari rumah merupakan hal yang mengejutkan bagi keluarga di Indonesia, khususnya bagi produktivitas orang tua yang memiliki pekerjaan di luar rumah. Kemudian dengan problem psikologis terhadap anak-anak peserta didik yang sudah terbiasa dengan pembelajaran tatap muka dengan guru. Semua elemen dalam pendidikan baik secara kehidupan sosial ikut terpapar sakit karena pandemi covid-19. Kedua adalah dampak jangka panjang. Banyak dari kelompok masyarakat di indonesia yang akan mengalami dampak jangka panjang dari pandemi covi-19. Dampak bagi pendidikan dari sisi waktu jangka panjang adalah pada aspek keadilan dan peningkatan ketidaksetaraan antar masyarakat dan antar daerah di Negara Indonesia (Aji, 2020).

Proses pembelajaran di sekolah merupakan alat kebijakan publik yang terbaik sebagai upaya peningkatan skill dan pengetahuan. Banyak siswa yang menganggap bahwa sekolah adalah kegiatan yang sangat menyenangkan, mereka dapat berinteraksi satu sama lain. Sekolah mampu meningkatkan keterampilan sosial serta kesadaran kelas sosial siswa. Sekolah secara keseluruhan adalah media interaksi antar siswa dan guru untuk meningkatkan skill, kemampuan integensi dan rasa kasih sayang diantara mereka. Tetapi 
saat ini kegiatan sekolah berhenti secara tiba-tiba karena pandemi Covid-19. Pandemi membuat sistem pembelajaran berubah drastis. Tidak hanya peserta didik, pendidik juga harus merancang kembali merancang pembelajaran yang singkat, jelas dan padat. Tentunya, keadaan seperti ini sangat berpengaruh terhadap produktivitas peserta didik maupun pendidik. Menteri Pendidikan, Nadiem Makarim menyatakan semangat untuk meningkatkan produktivitas bagi peserta didik guna mengangkat peluang kerja pada saat lulus sekolah. Tetapi, dengan datangnya wabah Covid-19 yang secara mengejutkan dan tiba-tiba membuat pendidikan di dunia khususnya Indonesia harus menyesuaikan diri dengan kondisi tersebut. Maka, pembelajaran tatap muka seperti biasa di sekolah harus berubah menjadi pembelajaran daring dari rumah masing-masing.

\section{B. Metode}

Penelitian ini merupakan penelitian studi literatur. Dengan menelaah beberapa buku dan jurnal mengenai Pendidikan Agama Islam dan Teknologi pendidikan untuk pembelajaran PAI. Hasil dari berbagai telaah literatur ini akan digunakan untuk mengindentifikasi manfaat dari teknologi untuk pembelajaran PAI di masa Pandemi covid19 ini.

\section{Hasil dan Pembahasan}

Pendidikan agama Islam (PAI) merupakan salah satu mata pelajaran yang mempunyai dua karakteristik. Pertama, pendidikan yang berisi tentang pengetahuan yang sarat akan nilai. Jadi, singkatnya mata pelajaran PAI ialah suatu mata pelajaran yang memberikan pendidikan moral, tidak hanya ilmu pengetahuannya saja. Pendidikan bisa diartikan sebagai suatu usaha yang dilakukan oleh sesorang yang mempunyai pengetahuan dalam hubungannya dengan oranglain untuk mengembangkan dan mengarahkan perkembangan jasmani dan rohani kea rah pendewasaan yang baik. Atau lebih tepatnya pemberian pendidikan kepada seseorang dalam masa pertumbuhan dan perkembangannya, dari aspek jasmani dan juga aspek rohani agar bermanfaat bagi diri sendiri, agama, masyarakat dan negara.

Maka dari itu, saat mendengar dan mengatakan tentang Pendidikan Agama Islam, akan terlintas dua hal, yaitu:

(a) Pendidikan yang mengajarkan peserta didik untuk selalu berperilaku baik sesuai dengan nilai-nilai, kebiasaan-kebiasaan sesuai Al-qur'an dan Sunnah.

(b) Pendidikan yang mengajarkan peserta didik untuk memahami isi ajaran agama Islam (Muhaimin, 2001).

Beberapa hal yang harus diperhatikan pada saat Pembelajaran Agama Islam, yaitu:

1. Usaha Sadar

Usaha sadar dalam PAI, yaitu kegiatan pembimbingan, pengajaran dan juga pelatihan yang dikerjakan dengan usaha sadar serta direncanakan untuk mencapai tujuan dalam pembelajaran.

2. Pencapaian Tujuan

Pendidik menyiapkan sistematika dalam pencapaian tujua dalam pembelajaran. Seperti, pemberian bimbingan sebagai upaya untuk meningkatkan keyakinan terhadap ajaran agama Islam.

3. Tugas Pendidik 
Memberikan bimbingan, pengajaran dan pelatihan dengan sadar tanpa paksaan kepada peserta didik guna tercapainya tujuan dari pendidikan tersebut.

\section{Arah Pendidikan}

Semua rangkaian kegiatan dalam pembelajaran PAI mengarah pada peningkatan kepercayaan atau keyakinan, penjelasan atau pemahaman, pendalaman dan mengaplikasian ajaran agama dari setiap peserta didik. Selain dapat membentuk keunggulan kepribadian, juga meningkatkan keimanan serta kepekaan sosial. Dalam arti, keunggulan pribadi seseorang itu diharapkan bisa dilakukan dalam kehidupan bermasyarakat tanpa memandang ras dan agama, serta dalam kehidupan berbangsa dan bernegara (Muhaimin \& Rahman, 2004).

Teknologi dalam pembelajaran Pendidikan Agama Islam adalah suatu cara disusun tersistem yang tentunya berupa harapan semua pendidik maupun peserta didik bisa menerima dan memahami materi yang diberikan dengan baik, tidak menyulitkan serta memberikan manfaat. Teknologi pembelajaran ini termasuk ke dalam teknologi pendidikan. Dasarnya ada pada konsep dari pendidikan yaitu pengajaran juga termasuk bagian darinya. Pengajaran dalam teknologi adalah perpaduan dari proses hubungan atau penyesuaian yang mengimplikasikan seseorang, gagasan, perangkat dan institusi serta cara-cara pengelolaan dalam memecahkan masalah pendidikan yang sering dihadapi ketika proses pembelajaran berlangsung dengan maksud yang direncanakan.

\section{Fungsi Teknologi Pembelajaran PAI}

Menurut Putri (2011) Fungsi teknologi berupa media diantaranya, yaitu:

a. Wadah bagi pendidik untuk memotivasi peserta didik yang memiliki semangat dan keinginan belajar yang kurang.

b. Wadah dan bahan ajar yang obyektif serta ilmiah.

c. Sebagai sarana untuk meningkatkan efektifitas dalam proses pembelajaran.

d. Wadah guna mempermudah pendidik dan peserta didik untuk melakukan presentasi didalam kelas.

e. Sebagai wadah untuk mempermudah penyajian desain dalam proses pembelajaran.

f. Sebagai sarana yang memudahkan peserta didik dalam menyampaikan materi pembelajaran.

g. Pendukung terlaksananya program pembelajaran jarak jauh yang lebih sistematis.

h. Sarana meningkatkan keberhasilan pembelajaran.

i. Sebagai media pendukung pelajaran dengan mudah.

\section{Teknologi dalam Pandangan Islam}

Islam sebagai agama rahmatan lil'alamin yang diturunkan Allah melalui nabi Muhammad SAW menjadi rahmat bagi seluruh makhluk yang ada di alam semesta. Pada perspektif islam, teknologi, ilmu pengetahuan, serta seni yaitu suatu pengembangan potensi manusia yang telah diberikan oleh Allah SWT yaitu berupa akal dan budi. Pada pengembangan ilmu pengetahuan dan teknologi (IPTEK) pada dasarnya untuk mengembangkan potensi serta akal pikiran yang telah Allah berikan kepada umatnya sesuai dengan sunnatullah dan bukan untuk menciptakan serta membuat diluar hukum yang telah Allah tetapkan. Islam sangat mendorong umatnya agar terus maju dengan 
menggali seluruh ilmu-ilmu yang ada baik melalui eksperimen dan juga penelitian. Teknologi selalu mengalami perkembangan seiring berkembangannya zaman dan membantu memudahkan urusan manusia misalnya dengan adanya internet untuk mecari segala informasi atau materi-materi pembelajaran yang dibutuhkan.

Para sejarawan muslim saat era kekhalifahan beranggapan sebagai suatu ilmu yang perlu untuk dipelajari serta untuk dikembangkan. Hal ini sesuai dengan penemuan oleh sejarawan sains di barat era modern di abad pertengahan. Begitu juga dengan ajaran Islam yang terbuka dan tidak bertolak belakang dengan teori pemikiran-pemikiran modern yang terorganisir, teliti, lugas, dan cermat dalam analisis dan objektif. Di dalam islam justru begitu mendukung kemajuan dalam teknologi yaitu dengan melalui penelitian-penelitian. Dalam Al- qur'an terdapat ayat-ayat Allah yang perlu dipelajari serta digali, misalanya dalam QS.Ali- Imran ayat 190-191 yang artinya: "Sesungguhnya dalam penciptaan langit dan bumi, dan pergantian malam dan siang terdapat tanda-tanda (kebesaran Allah) bagi orangorang yang berakal, (yaitu) orang-orang yang mengingat Allah sambil berdiri, duduk, atau dalam keadaan berbaring, dan mereka memikirkan tentang penciptaan langit dan bumi (seraya berkata), "Ya Tuhan kami, tidaklah engkau menciptakan semua ini sia-sia, Mahasuci engkau, lindungilah kami dari azab neraka." Ayat ini dengan lugas menjelaskan segala sesuatu baik ada di langit dan di bumi penuh dengan rahasia agar kita mencari tahu kebenarannya yaitu dengan melakukan penelitian yang mana diharapkan membantu kemudahan bagi umat yang bermanfaat termasuk dalam bidang teknologi itu sendiri. Pesatnya kemajuan teknologi modern telah mempopulerkan produk teknologi yang begitu canggih seperti internet, perangkat alat komunikasi, televisi, serta barang mewah lainnya yang memberikan berbagai hiburan dan tontonan baik anak-anak, remaja, maupun orang tua. Akan tetapi tentu saja alat- alat tersebut yang digunakan memiliki dampak, baik positif maupun negative dan hal itu mereka tidak ikut bertanggung jawab terhadap yang mereka sebabkan nantinya. Namun, hal itu ada pada pundak manusia atau penggunalah. Begitu banyak dan beragamnya alat-alat yang canggih serta media informasi yang ada di dunia kini begitu mudah melakukan apapun, yang ditentukan oleh faktor manusia dalam pengoperasiannya.

\section{Peran dan Manfaat Teknologi Pada Mata Pelajaran PAI di Masa Pandemi Covid-19}

Teknologi menurut AECT 2004, adalah "Educational technology is the study and ethicalpractice of facilitating learning and improving performance by creating, using and managing appropriate technological processes and resourcef,. Merupakan studi dan etika praktik dalam upaya memfasilitasi pembelajaran dan meningkatkan kinerja dengan cara menciptakan, menggunakan atau memanfaatkan dan mengelola proses dan sumbersumber teknologi yang tepat.

Penggunaan media dalam aktivitas pembelajaran di masa pandemi Covid-19 dapat dilakukan baik secara individu maupun kelompok. Jenis media pembelajaran yang dimaksud diantaranya adalah sebagai berikut (Wati, 2016)

a. Multimedia

Multimedia adalah penggabungan beberapa elemen informasi sebagai bagian dari upaya penyampaian tujuan. Seperti, teks, foto, vidio dan lain sebagainya, (Wati, 2016).

b. Media Elektronik

Terdapat bermacam media elektronik yang kerap dipakai pada saat pembelajaran, seperti slide dan lain sebagainya (Ibrahim \& Syaodih, 1996). 


\section{c. Komputer}

Komputer adalah sebuah perangkat elektronik yang digunakan untuk membantu pendidik maupun peserta didik dalam melakukan proses pembelajaran seperti, mencari informasi, mengolah data dan lain sebaiknya.

\section{d. Media Cetak}

Media cetak disebut sebagai suatu media untuk menyampaikan informasi kepada khalayak ramai yang dibuat melalui percetakan, seperti buku, majalah dan lain sebagainya.

e. Internet

Internet merupakan sitem seluruh dunia yang berfungsi untuk menghubungkan jaringan-jaringan komputer. Kumpulan jutaan jaringan komputer yang selalu berubahubah menyesuaikan dan melayani miliaran pengguna di seluruh dunia (Smaldino dkk, 2011)

f. Media Audio Visual

Media audio visual adalah sebuah media yang menayangkan suatu gambar yang bisa dilihat dan suara yang bisa didengar dengan bersama-sama seperti, vidio.

\section{g. Media Visual}

Media visual adalah sebuah perangkat atau alat yang digunakan oleh pendidik pada saat proses belajar mengajar. Media visual menyediakan sesuatu yang bisa dinikmati menggunakan panca indera atau penglihatan seperti, pembelajaran menggunakan proyektor.

h. Microsoft Power Point

Microsoft Office Power Point adalah sebuah aplikasi yang mempermudah pendidik ataupun peserta didik untuk melakukan presentasi dengan menggunakan tampilan slide.

Menurut Indriana (2011) Teknologi memiliki peran sebagai berikut:

a. Menerangkan konsep yang sulit dimengerti, dengan memanfaatkan teknologi konsepkonsep yang abtrak tersebut bisa dijelaskan dengan detail, cepat dan tepat. Seperti menjelaskan tentang kisah Nabi Nuh As.

b. Mendatangkan alat atau benda yang tidak aman atau sulit ditemukan di lingkungan sekolah. Contohnya, guru membutuhkan buaya, ular dan unta untuk menjelaskan materi yang akan diajar.

c. Memperlihatkan objek yang terlalu besar dan terlalu kecil. Contohnya, pendidik memberikan gambaran sebuah perahu Nabi Nuh As, Ka'bah dan memberikan objek yang teralalu kecil seperti, nyamuk, bakteri dan lain sebagainya.

d. Menampilkan gerakan yang terlalu cepat dan terlalu lambat. Teknologi bisa membantu dengan penggunaan pengaturan mode slow motion contohnya ketika sebuah film menayangkan tentang suatu ledakan.

e. Teknologi menjadi solusi pembelajaran daring yang dilakukan dirumah dengan menggunakan e-learning. Dan masih banyak platform lain yang berperan seperti, google meet, google classroom, zoom dan lain sebagainya.

Teknologi memiliki manfaat sebagai berikut:

a. Teknologi menyajikan peluang bagi peserta didik untuk bersosialisasi dan berinteraksi secara langsung dengan lingkungan di sekitarnya .

b. Memudahkan tercapainya tujuan pendidikan di masa pandemic Covid-19. 
c. Mempermudah pendidik membuat desain pembelajaran.

d. Pendidik dapat mengefisiensikan waktu.

e. Peserta didik harus berpikir lebih dalam untuk memahami materi yang disampaikan secara daring.

f. Teknologi membuat pembelajaran menjadi lebih menarik sehingga memotivasi peserta didik untuk semangat belajar.

g. Penyajian informasi atau materi ajar secara tepat waktu dan dapat disimpan sehingga peserta didik bisa membuka kembali materi jika belum dipahami.

h. Mempermudah pemberian informasi dan materi ajar, sehingga semua peserta didik secara bersamaan mengetahui instruksi yang diberikan oleh pendidik.

i. Teknologi membantu peserta didik untuk belajar dimanapun dan kapanpun selama masih terkoneksi dengan jaringan internet.

j. Pendidik bisa mengontrol situasi dan pencapaian belajar peserta didik walaupun tidak bertatap muka seperti biasanya (Safei, 2013).

\section{Contoh Pemanfaatan Teknologi Dalam PAI}

Teknologi menjadi salah satu strategi baru untuk mendukung proses pembelajaran. Dalam proses pembelajaran memiliki aspek penting yaitu kemampuan siswa dan guru agar bisa melakukan komunikasi tanpa batas waktu dan ruang. Ketika pembelajaran luring, ketika kegiatan pembelajaran di kelas selesai, maka interaksi antara guru dan siswanya pun berakhir. Zaman sekarang, teknologi informasi memberikan banyak inovasi ke semua orang. Begitu juga dengan guru yang mengajar pendidikan agama islam. Bisa kita ambil contoh, semisal pembelajaran berbasis internet, penggunaan elearning/telematika, blog, video conference (Zoom,Gmeet, dll). Menurut Arif (2011) Adapun contoh teknologi pada mata pelajaran PAI adalah :

1. Penggunaan kompas untuk menentukan arah kiblat.

2. Vidio/foto tentang tata cara shalat dll.

3. Alquran digital untuk mencari/menemukan surah, ayat dengan cepat.

4. Memanfaatkan fitur pada internet yang ada seperti e-mail, blog, elearning.

\section{Dampak Perkembangan dan Kemajuan Teknologi Pada Pembelajan Pendidikan Agama Islam.}

Selain teknologi berperan dalam pendidikan Islam, pendidikan agama Islam juga memiliki peran terhadap perkembangan teknologi. Pertama, aqidah dan akhlak, menjadi dasar atau landasan dalam pengoperasian atau pengaplikasian teknologi. Supaya menjadi terarah dan tidak menyebabkan terjadinya hal-hal negatif pada saat menggunakan teknologi. Kedua, hukum syariah yang menjadi tolak ukur penggunaan teknologi. Seperti penetapan baik, buruk, halal, haram dalam penggunaan teknologi.

Dampak perkembangan dan kemajuan teknologi sangat tampak dalam dunia pendidikan khususnya pendidikan agama Islam untuk menjawab pertanyaan seputar agama sesuai kandungan Al-qur'an dan Hadits, yaitu;

1. Meningkatkan motivasi peserta didik untuk kreatif mengembangkan teknologi yang bersumber dari nilai-nilai Islam.

2. Meningkatkan keterampilan dalam penggunaan teknologi untuk mensejahterakan masyarakat sekitar.

3. Mewujudkan hubungan silaturahmi antara agama dan teknologi. 
4. Menambah wawasan dan mengetahui kemampuan dalam menggunakan teknologi sesuai atau bersumber dari ajaran agama.

\section{Kesimpulan}

Pendidikan islam adalah usaha sadar dan terencana untuk membentuk peserta didik agar memiliki keseimbangan jasmani dan rohani, serta memiliki iman, ilmu dan amal sekaligus. Sedangkan, Teknologi adalah suatu wadah atau sarana yang menyajikan segala hal yang diperlukan oleh semua orang dalam memenuhi kebutuhan untuk menjalankan kehidupan. Bagi pendidikan itu sendriri teknologi merupaka salah satu sumber informasi yang digunakan untuk meningkatkan dan menambah pengetahuan. Teknologi mempunyai banyak fungsi seperti menyelesaikan suatu masalah, mengembangkan kreativitas dan mempermudah pendidik maupun peserta didik pada saat proses pembelajaran berlangsung. Islam sangat menuntun umatnya untuk terus mengali segala potensi yang ada pada dirinya demi kemaslahatan bersama, misalnya dengan mengembangan teknologi pendidikan salah satunya. Teknologi sangat bermanfaat bagi pendidikan terutama pada proses pembelajaran PAI, mempermudah guru menyampaikan materi ketika mengajar pada saat pembelajaran tatap muka maupun pembelajaran daring pada saat pandemi Covid-19.

\section{Daftar Pustaka}

Aji, R.H.S. (2020). Dampak Covid-19 pada Pendidikan di Indonesia: Sekolah, Keterampilan, dan Proses Pembelajaran. Jurnal Sosial \& Budaya Syar-i Vol. 7 No. 5.

Arif, K. (2011). Teknologi Pembelajaran Pai (Pendidikan Agama Islam) Dalam Paradigma Konstruktivistik, Jurnal Fikroh. Vol 4 No. 2.

Ibrahim, R., \& Syaodih, N. (1996). Perencanaan Pengajaran. Jakarta: Rineka Cipta.

Indriana, D. (2011). Ragam Alat Bantu Media Pengajaran, Jogjakarta: Diva Perss.

Muhaimin, A.G., \& Rahman, N.A. (2004) Paradigma Pendidikan Islam. Bandung: PT. Remaja Rosdakarya.

Muhaimin. A.G. (2001). Paradigma Pendidikan Islam; Upaya Mengefektifkan Pendidikan Islam di Sekolah. Bandung: PT. Remaja Rosdakarya.

Putri, A. (2011). Psikologi Perkembangan. Surakarta: PGSD UMS.

Safei. (2013). Teknologi Pembelajaran: Pengertian, Pengembangan dan Aplikasinya, Makassar: Alauddin University Press.

Smaldino, S.E., Lowther, D.L., \& Russell, J.D. (2011). Instructional Technology \& Media For Learning, terj. Arif Rahman, Teknologi Pembelajaran dan Media untuk Belajar, Ed. Ke-9, Jakarta: Kencana.

Wati, E.R. (2016). Ragam Media Pembelajaran, Surabaya: Kata Pena. 